\title{
SERUIM ELECTROLYTE ESTIMATATION AS AN EARLY PREDICATOR FOR GRADING SEVERITY KEY WORDS: OF HEPATIC ENCEPHALOPATHY
}

\section{Dr. Sonu Kumar M.D.Senior Resident,upgraded Depatement Of Pediatrics,pmch,patna. \\ Dr. Anuradha \\ Singh* \\ Dr. Prashant \\ Kumar \\ M.D. Assistant Professor,upgraded Departement Of Pediatrics,pmch,patna. *Corresponding Author}

*AIMS AND OBJECTIVES:-

1) Alteration in the level of Serum Sodium, Potassium and Chloride in hepatic encephalopathy.

2) Correlation of these levels with severity of hepatic encephalopathy due to various causes.

3) The role of Serum Sodium, Potassium and Chloride as a predictor for grading of severity of hepatic encephalopathy.

*STUDY-DESIGN: - Prospective observation study

(a) Inclusion criteria:-

All children with clinical and biochemical evidence of liver dysfunction having neuropsychiatric changes were included.

\section{(b) Exclusion criteria:-}

Cases with meningioencephalitis and other cases of encephalopathy will be excluded.

* SETTING:-

Upgraded department of Paediatrics, PMCH, Patna.

*STUDY GROUP:- All children with hepatic encephalopathy, they were admitted in paediatrics ward of Patna Medical College and Hospital, Patna, during the period of Jan 2018 to Dec-2019.

*PLAN FOR STATISTICAL ANALYSIS:-

Statistical analysis was done by using Descriptive Statistics, Standard Deviation, Standard Error of Mean and using SPSS Software.

\section{INTRODUCTION:-}

Hepatic encephalopathy is a complex neuropsychiatric syndrome characterised by disturbances in consciousness and behaviour, personality changes, fluctuating neurological signs, asterixis or "Flapping tremor" and distractive EEG changes in a patient with liver dysfunction.

Liver is the principal organ that performs a wide variety of functions. It maintains Carbohydrate, Protein and fat metabolism and has dominant role in synthesis of cougulation factors, Protein and Enzymes. Liver also attributed with a significant role in the maintenance of electrolyte metabolism. It is evident that there is hyponatraemia. It is evident that there is hyponatraemia in patient of hepatic encephalopathy, the relation of these changes in serum sodium, Potassium and Chloride should be known and established My study provides information about the changes in serum electrolytes could serve as a poor prognostic index but there was no correlation between serum electrolytes changes in patients of hepatic encephalopathy during different stages of hepatic encephalopathy.

\section{*MATERIALS AND METHODS:-}

All children with hepatic encephalopathy they were admitted in Paediatric ward of PMCH, Patna during the period of Jan 2018- Dec 2019. Since, PMCH is the best Post Graduate College in eastern side of India; it caters the whole of Bihar and adjacent areas. So, my study will reflect the current status of hepatic encephalopathy in our state.

\section{INCLUSION CRITERIA:-}

All children with clinical and biochemical evidence of liver dysfunction having neuropsychiatric changes were included.

\section{EXCLUSION CRITERIA:-}

Cases with meningioencephalitis and other causes of encephalopathy will be excluded.

\section{STUDY DESIGN:-}

Prospective observational study

\section{SETTINGS:-}

Upgraded department of paediatrics, $\mathrm{PMCH}, \mathrm{Patna}$

Materials and method included

- General information about patient

- Chief complaints

- History of presenting illness

- History of precipitating factors

- Past history, family history, immunisation history

- Anthropometry

- General Physical examination

- Signs of liver failure

- Systemic examination include gastro intestinal system, central nervous system, cardio vascular system, Respiratory system

\section{Lab Parameters included:-}

- Haemoglobin percentage,TC,DC,ESR, Platelets and PBS

- Blood urea, serum creatinine,RBS

- TSP, albumin, billirubin, AST, ALT and alkaline phosphate

- PT,Serum ceruloplasmin

- Viral marker. HBSAg, Anti HCV, IgM HAV, IgM HEV

- Laptospira serology, if needed

- Blood culture

- Routine Urine examination

- Ascitic fluid study

- Chest x-ray

- USG whole abdomen

- ABG

Stastical Formula employed:-

- Standard deviation

- Standard error of mean

\section{OBSERVATION AND RESULTS:-}

- Observation on Serum Sodium, Potassium and chloride out in 50 healthy subject (control group) and in 120 patient suffering from hepatic encephalopathy due to various etilogy. 
- The level of Serum Sodium, Potassium and Chloride were estimated in all individuals of control group. In the study group, the level of Serum $\mathrm{Na}^{+}, \mathrm{K}^{+} \& \mathrm{Cl}^{-}$were estimated on the day of admission, $3^{\text {rd }}$ day and $7^{\text {th }}$ day of admission.

- In control group, mean Serum Sodium level was $140.286 \pm$ $38.64 \mathrm{mmol} / \mathrm{lit}$. The mean serum potassium level was 4$\pm 0.29 \mathrm{mmol} / \mathrm{lit}$. The mean Serum Chloride level was $100.20 \pm 2.65 \mathrm{mmol} / \mathrm{lit}$.

- In study group, mean Serum Sodium level on day 1 was $126 \pm 6.95 \mathrm{mmol} / \mathrm{lit}$ and on day 3 was $128 \pm 6.95 \mathrm{mmol} / \mathrm{lit}$ and on day 7 was S.Na level was $134.13 \pm 7.14 \mathrm{mmol} / \mathrm{lit}$. S.Na ${ }^{+}$level highly signifies full $p$ value $<0.001$ on day 1,3 and7.

\begin{tabular}{|c|c|c|c|c|c|c|c|c|c|c|}
\hline \multicolumn{3}{|c|}{$\begin{array}{l}\text { Serum } \mathrm{Na}^{+} \text {in } \mathrm{m} \mathrm{mol} / \mathrm{L} \text { in } \\
\text { control group }\end{array}$} & \multirow[t]{2}{*}{$\begin{array}{l}\text { Study } \\
\text { Group }\end{array}$} & \multirow[t]{2}{*}{ Days } & \multicolumn{3}{|c|}{ Serum Sodium in $\mathrm{m}$ mol/L in study group } & \multirow[t]{2}{*}{ Value } & \multirow[t]{2}{*}{$\begin{array}{c}P \\
\text { Value }\end{array}$} & \multirow[t]{2}{*}{ Remark } \\
\hline Mean & S.D & S.E.M & & & Mean & SD & S.E.M & & & \\
\hline \multirow[t]{3}{*}{140.02} & \multirow[t]{3}{*}{ \pm 2.86} & \multirow[t]{3}{*}{ \pm 0.404} & & $1^{\text {st }}$ day & 126.10 & \pm 6.95 & \pm 0.634 & 13.66 & $<0.001$ & Highly Significant \\
\hline & & & & $3^{\text {rd }}$ day & 128.70 & \pm 6.95 & \pm 0.685 & 11.09 & $<0.001$ & Highly Significant \\
\hline & & & & $7^{\text {th }}$ day & 134.13 & \pm 7.14 & \pm 0.744 & 5.64 & $<0.001$ & $\begin{array}{c}\text { Highly } \\
\text { Significant }\end{array}$ \\
\hline
\end{tabular}

In control group, the mean serum sodium level is $140.02 \mathrm{mmol} / \mathrm{L}$. In study group the mean serum sodium level

on day 1 is $126.10 \mathrm{mmol} / \mathrm{L}$, on day 3 is $128.70 \mathrm{mmol} / \mathrm{L}$ and on day 7 is $134.13 \mathrm{mmol} / \mathrm{L}$.

Table - 17 Showing statistical evaluation of changes in the level of Serum Potasium in study group with that of control group

\begin{tabular}{|c|c|c|c|c|c|c|c|c|c|c|}
\hline \multicolumn{3}{|c|}{$\begin{array}{l}\text { Serum } \mathrm{k}+\text { in } \mathrm{m} \mathrm{mol} / \mathrm{L} \text { in } \\
\text { control group }\end{array}$} & \multirow[t]{2}{*}{ Study Group } & \multirow[t]{2}{*}{ Days } & \multicolumn{3}{|c|}{ Serum potassium in $\mathrm{m} \mathrm{mol} / \mathrm{L}$ in study group } & \multirow[t]{2}{*}{$\begin{array}{c}\text { Z } \\
\text { Value }\end{array}$} & \multirow[t]{2}{*}{ P Value } & \multirow[t]{2}{*}{ Remark } \\
\hline Mean & S.D & S.E.M & & & Mean & $\mathrm{SD}$ & S.E.M & & & \\
\hline \multirow[t]{3}{*}{4.0} & \multirow[t]{3}{*}{ \pm 0.292} & \multirow[t]{3}{*}{ \pm 0.084} & & $1^{\text {st }}$ day & 3.00 & \pm 0.794 & \pm 0.115 & 8.70 & $<0.001$ & Highly Significant \\
\hline & & & & $3^{\text {rd }}$ day & 3.27 & \pm 0.816 & \pm 0.104 & 6.10 & $<0.001$ & Highly Significant \\
\hline & & & & $7^{\text {th }}$ day & 3.58 & \pm 0.876 & \pm 263 & 3.27 & $<0.01$ & Significant \\
\hline
\end{tabular}

In control group, the mean serum potassium level is on day 1 is $3.00 \mathrm{mmol} / \mathrm{L}$, on day 3 is $3.27 \mathrm{mmol} / \mathrm{L}$ and on day 7 is $4.00 \mathrm{mmol} / \mathrm{L}$. In study group the mean serum potassium level $3.58 \mathrm{mmol} / \mathrm{L}$

Table - 18 Showing statistical evaluation of changes in the level of Serum Chloride in study group with that of control group

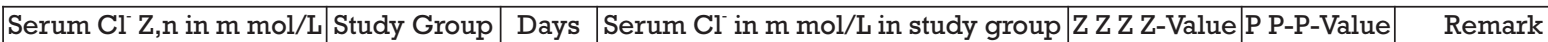
in control group

\begin{tabular}{|c|c|c|c|c|c|c|c|c|c|}
\hline \multicolumn{3}{|l|}{ III } & & & & & \\
\hline Mean & S.D & S.E.M & & Mean & SD & S.E.M & & & \\
\hline \multirow[t]{3}{*}{100.20} & \multirow[t]{3}{*}{ \pm 2.65} & \multirow[t]{3}{*}{ \pm 0.375} & $1^{\text {st }}$ day & 98.74 & \pm 5.99 & \pm 0.547 & 1.65 & $>0.05$ & Not Significant \\
\hline & & & $3^{\text {rd }}$ day & 100.25 & \pm 4.87 & \pm 0.480 & 0.06 & $>0.05$ & Not Significant \\
\hline & & & $7^{\text {th }}$ day & 101.11 & \pm 5.29 & \pm 0.551 & 1.16 & $>0.05$ & Not Significant \\
\hline
\end{tabular}

In control group, the mean serum chloride level is $100.20 \mathrm{mmol} / \mathrm{L}$. In study group the mean serum chloride level on day $l$ is $98.74 \mathrm{mmol} / \mathrm{L}$, on day 3 is $100.25 \mathrm{mmol} / \mathrm{L}$ and on day 7 is $101.11 \mathrm{mmol} / \mathrm{L}$.

\section{SURVIOVORV/S NON SURVIVOR:-}

From the above observation, it is clear that the serum sodium and the Serum Potassium and Serum Chloride level has decreased on patient of hepatic-encephalopathy.
The 67 patient who survived and recovered from hepatic encephalopathy, the level of serum $\mathrm{Na}^{+}$and $\mathrm{K}^{+}$were decreased at $1^{\text {st }}$ day showed insignificant changes but patients who not survived and not recovered from hepatic encephalopathy, the level of sodium and potassium were decreased on day $1^{\text {st }}$ and does not showed improvement on late phase (on day 7) in them the level of Chloride showed insignificant changes.

Table - 22 Comparison of electrolytes level in survivors and non-survivors of study group

\begin{tabular}{|c|c|c|c|c|c|c|}
\hline \multirow[t]{2}{*}{ Days when Sample taken } & \multicolumn{2}{|c|}{ S. Sodium level (Mean) } & \multicolumn{2}{|r|}{$\mathrm{K}^{+}$} & \multicolumn{2}{|r|}{$\mathrm{Cl}^{-}$} \\
\hline & Survivor & non Survivor & Survivor & non Survivor & Survivor & non Survivor \\
\hline $1^{\text {st }}$ day & 127.05 & 124.90 & 3.09 & 2.88 & 98.14 & 99.49 \\
\hline $3^{\text {rd }}$ day & 130.38 & 125.58 & 3.43 & 2.98 & 100.04 & 100.63 \\
\hline $7^{\text {th }}$ day & 135.85 & 129.52 & 3.75 & 3.11 & 101.52 & 100.04 \\
\hline
\end{tabular}

Serum sodium level,in survivor on day 1 is $127.05 \mathrm{mmol} / \mathrm{l}$, on day 3 is $130.38 \mathrm{mmol} / 1$ and on day 7 is $135.85 \mathrm{mmol} / 1$.In non survivor,serum sodium level on day $l$ is $124.90 \mathrm{mmol} / 1$, on day 3 is $125.58 \mathrm{mmol} / \mathrm{l}$ and on day 7 is $129.52 \mathrm{mmol} / 1$

Serum potassium level,in survivor on day 1 is $3.09 \mathrm{mmol} / \mathrm{l}$, on day 3 is $3.43 \mathrm{mmol} / 1$ and on day 7 is $3.75 \mathrm{mmol} / \mathrm{l}$.In non survivor,serum potassium level on day 1 is $2.88 \mathrm{mmol} / \mathrm{l}$, on day 3 is $2.98 \mathrm{mmol} / \mathrm{l}$ and on day 7 is $3.11 \mathrm{mmol} / 1$.

Serum chloride level in survivor group on day 1 is 98.14 $\mathrm{mmol} / \mathrm{l}$,on day 3 is $100.04 \mathrm{mmol} / \mathrm{l}$ and on day 7 is 101.52 $\mathrm{mmol} / \mathrm{l}$.In non survivor,serum chloride level on day $\mathrm{l}$ is 99.49 mmol.l,on day 3 is $100.63 \mathrm{mmol} / \mathrm{l}$ and on day 7 is 100.04 $\mathrm{mmol} / \mathrm{l}$.

\section{DISCUSSION:-}

From the observation, it is clear that both the Serum Sodium and Serum Potassium level has decreased in patient of hepatic encephalopathy.

The size of hyponatraemia in case of hepatic failure of various etilogies , have been reported from time to time. Donald et al, Swartz et al (1954),Artmem et al, Nancer, Chettrietal, Parbha et al, Pride et aland Vaish Warner at al have all reported of hyponatraemia in case of hepatic failure. Prabha et al had 
reported hyponatraemia $\left(\mathrm{S} . N a^{+}<125\right.$ mean/LA) in $52 \%$ cases. Vaish Warner et al observed mean serum sodium level was 130 mean/LA. Wilkinson et al and Sheila Sherlock have reported that hyponatraemia and hypokalaemia is observed in patients of fulminant hepatic failure.

Nacker, Sherlock and Ring Larson have commented on the poor prognosis of patients with hyponatraemia in hepatic failure. The mortality in such cases is as high as $82 \%$ according to them serum sodium below 130mean/LA must be regarded as serum and if below $125 \mathrm{mean} / \mathrm{LA}$ ominous. This hypo $\mathrm{Na}^{+}$is not amenable to treatment and reflects impending cell death rather than body sodium losses. They have also contained against the use of RV saline in such cases. In current study mortality is $44 \%$, when mean serum sodium level 124 mean/LA on day 1,125 mean/LA on day 3 and 129.52 mean/LA on day 7 . In current study vomiting and GL bleeding maybe contributing factor is causing hyponatraemia. Vomiting and GL bleeding was noted $76 \%$ and $52 \%$ of cases of study group. Many hypothesis regarding change of electrolyte concentration of sodium in hepatic cellular failure have been observed by various other and may be caused by determining vomiting and desicite intake. As suggested by Donald et al it may be due to diluternal effect.

- Hyponatraemia may be because of primary release of cell $\mathrm{K}^{+}$due to metabolic disturbances as result of desire process there by effecting the osmolarim of cellular system or process there by affecting may be due to alteration in of osmotic caution to total body water (Sims et al, Jhonson et al, Narpson et al. Talsco et al have shown that the total exchangeable sodium is increased in some patients with hyponatraemia although total body water was normal or slightly increase.

- The stat of $\mathrm{v}$ hyponatraemia in hepatic encephalopathy of various etilogies has been reported time to time. Altman et al studied 30 patients of cirrhosis in hepatic cellular failure and hepatic coma and found hypokalemia $\mathrm{K}^{+}$in 25 patients.

- I.V. infusion of glucose which is usually gives as the treatment of hepatic coma also causes fall in Serum $\mathrm{K}^{+}$ level. Glucose loading is well known to lower potassium apparently because potassium is needed in glycogen formation and the withdrawal from extra cellular reserves during accelerated metabolism. The mechanism of hypokalemia $\mathrm{K}^{+}$is uncertain. hypokalemia $\mathrm{K}^{+}$has been observed in patients with normal total body $\mathrm{K}^{+}$(Tofler et al) and in the absence of -ve potassium balance (Neinman). The hypokalaemia may be due to failure of renal conservation of potassium in hepatic failure (Mandel et al) and altered state of cellular metabolism may be cause of loss of potassium balance. However urinary loss of potassium is said to be high fulminate cell failure (Tray and Davidson). Neuro Psychiatric changes following the use of thyroids diuretics has been associated with hypokalaemia (Read et al) correction of potassium efficiency even though diuretics was continues improved the neuro psychiatric state. Potassium deficiency increase ammonia output into renal vain (Baertle et al) and this has related to the encephalopathy, hypokalaemia is associated with alkalosis and this allow more ammonia to penetrate the blood brain barrier. Swartz et al, foulk et al and Gosh and Kanan et al found significant, low level of serum chloride in causes of hepatic coma various etiologies. But Sherlock et al in an observation of the complications of diuretics therapy in

In this study, patients with hypokalaemia does not showed significant fall of chloride level, the difference between our study and previous study may be due to small sample size and previously with different types of fluid.

In consideration of above discussion it is clear that hypokalaemia is observed in HE. These eleclyte changes are related to the liver function and could serve as poor prognosis index.

\section{CONCLUSION:-}

- The present work is the study to evaluate changes in the Sodium electrolyte level in children suffering from hypokalaemia.

- The of HE contesting of 70 male children and 50 female children were included in the study group. They were admitted in paediatric ward of PMCH, Patna from Jan 2018 to Dec 2019. The following points are inferred from the study.

- As compared to the control group there was highly significant fall of serum $\mathrm{Na}^{+} \& \mathrm{~K}^{+}$level still. They did not achieve the level of mean of control grope by $7^{\text {th }}$ day.

- In patients, who referred from HE there was highly significant fall of serum $\mathrm{Na}^{+}$and $\mathrm{K}^{+}(\mathrm{P} \leq 0.001)$ which gradually improved in $7^{\text {th }}$ day and who did not recover from $\mathrm{HE}$ there was highly significant fall of mean serum $\mathrm{Na}^{+}$and $\mathrm{K}^{+}(\mathrm{P}<0.001)$ who did not improve after . in these patient there was no significant change in $\mathrm{Cl}^{-}$level. A significant Hypo $\mathrm{Na}^{+}$, Hypo $\mathrm{K}^{+}$and hypo $\mathrm{Cl}^{-}$were observed in study group.

\section{REFERENCES}

1. Pessoa MG. Terrault MA, Detmer J, Et al. Quantitation of hepatitis G and C viruses in the liver: evidence that hepatitis $\mathrm{G}$ virus is not hepatottrophic. Hepatology 1998;27:877-80.

2. Kuwada SK, Patel VM, Hollinger FB, et al.Non-A, Non- B fulminant hepatitis is also no-E and no-C.Am J Gastroenterol 1994;89:57-61.

3. Gimson AES, white YS, eddleston ALWF, et al. Clinical and prognostic differences in fulminant hepatitis type A, B and non- A, non-B, gut 1983; 24 : 1994-8.

4. Khuroo M.S. Acute liver failure in India. Hepatology 1997;26:244-6

5. Srivastava KL, Mittal A, Kumar A, et al. Predictors of outcome in fulminant hepatic failure in children. Indian J Gastroenterol 1988; 17:43-5.

6. Diris L, Polson RJ, Richardson A, et al. Primary sepsis Presenting as fulminant hepatic failure. QJ Med 1989;271:1037-43.

7. Bhaduri B, Lau JYN, Heaton N, et al. Acute hepatic failure in childhood etiology, prognostic indicators and role of orthotopic liver transplant. J paediatr Gastroenterol Nutr 1992; 15:342. (Abstract).

8. Tibbs C, Williams R, viral causes and management of acute Jiver failure. J Hepatol 1995;22(Suppl);68-73.

9. Schiodt FV, Atillasoy E, Shakil AO et al. Etiology and outcome for 295 patients with acute liver in the united state. LiverTranspl Surg 1999:5:29-34.

10. Zimmerman HJ, MaddreyWC. Acetaminophen (Paracetamol). Hepatotoxicity with regular intake of alcohol: analysis of instance of therapeutic misadventure. Hepatology 1995;22:767-73.

11. LeeWM.Drug induced hepatotoxicity.N Engl J Med 1995;333:1118-27.

12. Arora NK, Jain S. Acute liver failure. In : Singh M editor. Medical emergencies in children. 3rd ed New Delhi:Sagar publication;2000. P 386-410.

13. TreemWR. Hepatic failure. In : walkerWA, Durie PR, Hamilton JR, Walker Smith JA, Watkins JB, editors. Pediatric gastrointestinal diseases. 2nd ed. Philadelphia:BC Decker Inc; 1996.P 353-4.

14. Podolsky OK, Isselbacher KJ. Derangemonts of hepatic mertabolism. In : Fauci AS, Braunwald E, Isselbacher KJ,Wilson JD, Martin JB, Kasper DL.Editors. Harrison's principles of internal medicine. 14th ed.Vol-2.Newyork :Mc GrawHill; 1998.P1667-72.

15. Mullen KD, Dasarathy S. Hepatic encephalopathy. In : Eugene RS, Michael FS, Willis CM. Editors. Schiff's diseases of the liver. Sth ed. Philadelphia Lippincott William Squires R. Liver failure. In : Rudolpt) CD, Rudolph AM, Hostetter MK, Lister G, Siegel MJ. Rudolph's paediatrics. 21 st ed.Newyork: Mc Graw-Hill;2002,p 1511-3.

16. Gammal SH, Jones EA. Hepatic encephalopathy. Med Clin N Am 1989; 73: 193 -808 .

17. Schenker S, Breen KJ, Hoyumpa AM. Hepatic enecephalopathy: Current status. Gastroenterology 1974;66:121-151.

18. Hoyumpa AM, Desmond PV, Avant GR et al. Encephalopathy. Gastroenterology 1979;76:184-96.

19. Bemuau J, Jean-Pierre B, Mc Intyre N, Rizzetto M, Rode's, editors. Oxford textbook of clinical hepatology 2 nd ed, vol.2.0 oxford:oxford university press; 1999.P1341-72.

20. Komori $\mathrm{H}$, Hirasa $\mathrm{M}$, Takakuwa $\mathrm{H}$ et al, Concept of the clinical stages of acute hepatic failure. Am J Gastroenterol 1986;544-9.

21. Khuroo MS. Acute liver failure. Ann Saud hi Med 1998; 18:318-26

22. Ede RJ,Williams R. Hepatic encephalopathy and cerebral edema. Semin Liver Dis $1986 ; 6: 107-123$

23. Wilkinson SP, Hurst 0, Portmann B et al. Pathologenesis of renal failure in cirrhosis and fulminant hepatic failure. Postgrad. MedJ;51:503-5.

24. Bihari OJ, Gimson AES, Williams R. Cardiovascular pulmonary and renal complication of fulminant hepatic failure. Semin Liver. Dis 1986;6: 119-28.

25. Rakela J, Lange SM, Ludwig J, et al. Fulminant hepatitis. Mayo clinic experience with 34 cases. Mayo Clin Proc 1985;60:289-92.

26. Alper G, Jarjour IT. Outcome of children with cerebral edema caused by fulminant hepatic failure. Pediatr Neurol 1998; 18:299-30 (Abstract)

27. Karvountzis GG, Redekar AG, Peters RL. Long term follow up studies of patients surviving fulminant viral hepatits. Gastroenterology 1974;67:870-77.

28. Diseases of the liver and Biliary System in children - By Deirdre A. Kellyt - 3rd edition (2008).

29. Dhawan A, Cheeesemen p, "approach to Acute liver failure in children" 
PARIPEX - INDIAN JOURNAL OF RESEARCH | Volume - 10 | Issue - 10 | October - 2021 | PRINT ISSN No. 2250 - 1991 | DOI : $10.36106 /$ paripex

Nelson text Book of Pediatrics 18th edition (2008).

30. Intikhab Alam, Razaullah, Iqual Haider, "Spectrum of precipitating factors of

hepatic encephalopathy"PJMR volume-44 (2005) 